\title{
The role of international experience in speed of entry: Empirical evidence from Chinese innovative firms
}

\author{
Hongping $\mathrm{Du}^{1}$, Maoyan $\mathrm{She}^{2}$, Xuan $\mathrm{Yu}^{3, *}$ \\ ${ }^{1}$ Business School, Sichuan University, 610065, Chengdu, China \\ ${ }^{2}$ College of Management Science, Chengdu University of technology, 610059, Chengdu, China \\ ${ }^{3}$ School of Life Science and Technology, University of Electronic Science and Technology, 611731, Chengdu, China
}

\begin{abstract}
By analyzing the dynamic path of internationalization, this study attempts to explain the entry mode choice, location choice, and speed of entry in the process of internationalization from the learning results obtained from previous international activities. Our research shows that the speed of the entry process depends on the type of experiential learning generated by the implicit decision-making in the process of Internationalization: the entry mode choice and the market location choice. We find that the experience accumulated in the host country has an inverted U-shaped effect on the speed of entry; while the experience accumulated of the entry mode has a U-shaped impact on the speed of entry. We perform an event history analyses(EHA) on 153 Chinese innovative firms with 905 OFDI observations during the period from 1991 to 2015, and analysis what and why is the paths of internationalization of Chinese firms. We find that Chinese innovative MNEs have more likelihood to choice the entry mode of acquisition and WOS than other entry modes in OFDI activity, and there is a higher probability that the Chinese innovative MNEs choice the market location of developed countries than developing countries in OFDI activity.Most importantly, we find that accumulated experience in host country has an inverted U-shaped impact on the speed of internationalization operation with acquisition mode and the speed of internationalization in developed countries; while accumulated experience in focal entry mode has an U-shaped impect on the speed of internationalization operation with branch or WOS mode and the speed of internationalization in developing countries. This claim is supported by both non-parametric and parametric tests in the EHA. Our research highlights the short-term and long-term consequences of different types of paths associated with the internationalization process.
\end{abstract}

\section{Introduction}

The new development pattern will bring China higher quality opening-up to the outside world. At present, China is committed to promoting a higher level of opening-up, promoting high-quality economic development, building a powerful economic and trade country, and creating a good development policy environment for "going out" enterprises to carry out foreign investment and cooperation[1]. According to the statistical data of "China's foreign investment cooperation development report 2020" released by the People's Republic of China Ministry of Commerce, China's foreign direct investment flow is 136.91 billion US dollars in the year of 2019, accounting for $10.4 \%$ of the global investment flow in that year, ranking second in the world after the United States. In the year of 2020, although COVID-19 has caused serious impact on the world economy, the Chinese government has made a decision to build a new development pattern of "domestic and international double circulation" as a main force. China's foreign investment cooperation will usher in new opportunities for development in terms of quality, efficiency, safety and sustainability.
Hence, the high-speed growth and the big scale of China's OFDI has drawn the attention of academics, business managers and policy-makers, and has resulted in increased research on this topic[2]. A review of the extant research on China's Outward FDI shows that most studies have examined the entry mode and market locations choice. The internationalisation path of Chinese firms is by no means universally observed[3]. Compared with the volume of research on the antecedents of the paths of internationalization and the influence of internationalization on the firms' performance, the area of research in the paths of internationalization has received the least attention.

Prominent recent work on the paths of internationalization is about the market locations choice, entry mode choice, and some about the pattern of internationalization. Some findings of the internationalization paths of Chinese MNEs from[4-7] were based on case study, other research focused on only one dimension witnin the choice of entry mode $[8,9]$, the choice of foreign market entry mode[10,11], and the entry timing. On one hand, previous studies lack a dynamic description about the internationalization trace of Chinese MNEs, especially they have ignored three dimensions of

* Corresponding author: yuxuan_0917@aliyun.com 
firms' internationalization (foreign location,entry mode and entry timing) at the same time. On the other hand, it's hard to avoid bias problem from the case study and questionnaire method, findings were difficult to represent the universal mode of Chinese MNEs' internationalization paths. As a result, despite the growing literature, our understanding about the internationalization paths that Chinese firms have formed and the factors that influence the Chinese MNEs to choose are limited.

This study will analyze the following issues: what is the paths of internationalization of Chinese enterprises? how does the past international experience affect the speed of international activity? We distinguish the learning of three standard internationalization decisions: entry mode, market location and speed of entry - and we put forward three hypotheses based on these three internationalization decisions. In order to explore our hypothesis, we conducted a longitudinal empirical study based on 905 OFDI events observations of 153 Chinese innovative firms during the period of 25 years (19912015).

This study helps to improve the understanding of the internationalization path of emerging multinationals, insofar as it: (1) analyzes dynamically of the three classic internationalization process decisions-entry mode choice, location choice, and entry speed; (2) adopts a longitudinal approach to study the influence of international experience as a dynamic capability on international choices; and (3) distinguishes the different effects of international experience on international decision-making. In summary, our contribution is to extend existing theories (path-dependent viewpoints and learning perspective) to the emerging economy MNEs' international context[12]; and to study the unique functional relationship of the international environment (the influence of the learning process on the path of internationalization).

\section{Literature review and hypotheses}

\subsection{Entry mode choice}

The previous research was more about the Chinese firm's decision-making in establishing joint ventures and wholly-owned subsidiaries[13], or the choice between greenfield investment and mergers\& acquisitions[10,14]. Cui and Jiang found that Chinese companies are more likely to become wholly-owned subsidiaries when adopting global strategies, face fierce host industry competition, and focus on finding assets in OFDI. However, if the company invests in a fast-growing host country, it is more likely to choice the entry mode of joint venture[13]. At the same time, some Chinese companies face huge knowledge differences, which hinder their competion on the global stage, and they frequently use acquisitions as a means to close these gaps $[10,15,16]$. Anderson and Sutherland found that "compared with the entry mode of greenfield investment, Chinese enterprises mainly through M\&A to seek strategic assets in the developed countries to carry out internationalization" [17].
Liou believes that the industrial sector will affect the overseas transactions of Chinese companies. For example, China's large oil and gas companies tend to choose M\&A due to lack of resources and similar M\&A transactions in the history of the industry[18].

Hypothesis 1 . There is a higher probability that the Chinese innovative MNEs choice the entry mode of acquisition and WOS than other entry modes in OFDI activity.

\subsection{Market location choice}

The overseas location selection of multinational companies is another important dimension of the internationalization path. Specifically, the research on the location selection of Chinese enterprises was mainly focused on the choice between emerging economies and advanced economies. Since China is a middle-income country, Chinese multinational companies not only do some OFDI activities in this developed countries that richer than China but also in other developing countries with lower income level[19,20]. Cuervo-Cazurra and Genc found that most EMNEs would choose to expand overseas in emerging economies because they have less supervision and control of corruption, and they have more operating room in overseas expansion through the system[21]. For example, some Chinese multinational companies tend to invest in certain tax havens and Southeast Asia countries[22]. However, Ramamurti found that the location choice of Chinese multinational companies may depend on the ownership structure. Stateowned enterprises tend to choose these regions with abundant natural resources and less political risks, while private enterprises pay more attention to the market size and production efficiency of the host country[23].

Hypothesis 2 . There is a higher probability that the Chinese innovative MNEs choice the market location of developing countries than developed countries in OFDI activity.

\subsection{International experience and speed of entry}

The internationalization process assumes that liability of foreignness are gradually reduced with the increase of corporate market commitments. Market commitment is developed through a learning process, during which companies acquire foreign marketing knowledge, institutional knowledge and foreign business knowledge[12]. Similarly, increasing network sites by accumulating experience in a focal market location decreases the liability of outsidership[24]. According to this, the speed of internationalization should be higher when firms do new OFDI business in countries where they have previous experience.

Hypothesis 3a. A higher accumulated experience in host country has a curvilinear influence on the speed of internationalization operation with acquisition mode (inverted-U form).

Hypothesis 3b. A higher accumulated experience in host country has a curvilinear influence on the speed of 
internationalization in developed countries(inverted- $U$ form).

Some similar situation is likely apply to the international entry mode. Each entry mode (branch, wholly-owned subsidiary, joint venture, acquisition, etc.) requires a different skill set. For example, in the case of international acquisition, different specific challenges have arisen, such as the ability to incorporate resources into the multinational companies and their acquired business[25].In the early stage of the internationalization process, firms often choose the lower commitment mode, such as establishing branches, leading to the speed of internationalization is high at the beginning. However, when a company adopts a deeper business mode of operation, the knowledge accumulated by this diversified experience will be higher, enabling speed to decrease, because they will choose a higher commitment entry mode. Thus, we propose a curvilinear relationship between the diversity of business mode of operation and the speed of the internationalization process:

Hypothesis 3c. A higher accumulated experience in focal entry mode has a curvilinear influence on the speed of internationalization operation with branch and WOS mode(U form).

Hypothesis 3d. A higher accumulated experience in focal entry mode has a curvilinear influence on the speed of internationalization in developing countries( $U$ form).

\section{Methodology}

\subsection{Data source}

We constructed an unbalanced panel dataset for the period of 1991-2015 to test our framework and hypotheses. Information on the OFDI activities of China's innovative companies comes from the Ministry of Commerce of the People's Republic of China(MOFCOM). In our research, the obtainable final data set includes 153 innovative companies with complete information. We further checked each investment event and checked the overseas entry modes (branch, JV,WOS and aquisition) from the website and annual reports of innovative firms. Finally, we left with 153 innovative firms with 905 OFDI observations during the 1991-2015 ${ }^{\mathrm{a}}$.

\subsection{Measurement of variable}

Dependent variables. The choice of entry methods that we measure for the dependent variables are as follows: 1 for creation of a branch, 2 for creation of a wholly-owned subsidiary, 3 for creation of a joint venture(JV), and 4 for an acquisition. Location choice is a dummy variable that represents the level of market locations choice, which is 1 for developed countries and 0 for developing countries[8]. The speed of entry has been measured as the number of

\footnotetext{
a Because the number of Chinese foreign subsidaries/branches varies each year, for example, it may be have 0 subsidiary/branches in 2000,3 subsidiary/branches in 2001, and 1 subsidiary/branches in 2010 . Therefore, it was impossible to build a balanced panel dataset.
}

days between the focal operation and the immediately prior operation of the same firm[12].

Independent variables. The host country experience is measured by the number of years a focal firm has conducted business in a specific host country since its first OFDI activity in that country[26]. The entry mode experience is measured according to the number of overseas subsidiaries/branches established by a focal firm has built with specific entry mode[27].

\subsection{Survival analysis}

Survival analysis usually carries on the investigation and observation to the occurrence of the event and the related factors that affect the occurrence of the event, and carries on the related statistical analysis to the law of its occurrence at the same time[28,29]. In this paper, we use the following two basic methods: (1)nonparametric method. The Kaplan-Meier product limit estimation method in the nonparametric method of survival function is mainly used[30]. This paper makes a related study on the OFDI activities selection of Chinese enterprises under the overall sample and different types of samples. (2)Semi-parametric method. Cox proportional risk model is used to study the influence of multivariable factors on entry mode and Location choice.

In survival analysis, a specific period is the survival time, which refers to the time from the beginning of a certain starting event to the occurrence of the terminal event of the observed object. Survival time is usually described by three functions: survival function $S(t)$; probability density function $f(t)$; risk rate function $h(t)$.

Survival function. Survival function $S(t)$ is the individual's survival time is greater than $T$. That is, the probability distribution of the failure event has not yet occurred until a certain point in time. In this study, it is assumed that the duration from the beginning of observation to the occurrence of OFDI events is a nonnegative random variable $T$. And the cumulative distribution function $F(t)$ is:

$$
F(t)=\int_{0}^{t} f(s) d s=\operatorname{Pr}(T \leq t)
$$

A complementary concept as a cumulative distribution function is that the duration of the unperformed OFDI is equal to or greater than $t$. The probability is a survival function. $S(t)$ Give out:

$$
S(t)=1-F(t)=\operatorname{Pr}(T \geq t)
$$

Probability density function. Because the survival time is a continuous numerical variable, it has a probability density function. Probability density function $f(t)$ was also known as the density function. The graph is called a density curve. The proportion of death and the peak value of the chance of death in any time range can be found from the density curve.The first order 
differential is carried out, and the probability density function is obtained. the expression of the function is as follows:

$$
f(t)=d F(t) / d t=-d S(t) / d t=\lim _{\Delta_{t}} \frac{P_{t}\left(P<T<t+\Delta_{t}\right)}{\Delta_{t}}
$$

Hazard function. $h(t)$ refers to the time when the duration of the OFDI is not performed by the enterprise $t$. The probability of instantaneous occurrence of OFDI is :

$$
h(t)=\lim _{h \rightarrow 0} \frac{\operatorname{Pr}[t \leq T \leq t+h]}{h}
$$

Consider a discrete case, set $t_{1}<t_{2}<\ldots<t_{k}$. It is the discrete life time that the sample can observe. Definition $d_{j}$ is the duration of the OFDI not performed at all times $t_{j}$. At the end of the research time, the OFDI schema that some enterprises have not yet studied or terminated at other events is the deleted data (censored data). Definition $m_{j}$, It's in the interval $\left[t_{j}, t_{j+1}\right]$. The number of samples with right deletion. Definition $r_{j}$, it's at the moment $t_{j}$. The number of samples previously available for possible OFDI is $r_{j}=\sum_{l \geq \mathrm{j}}^{k}\left(d_{l}+m_{l}\right)$. Therefore, the Kaplan-Meier estimator of the survival function is:

$$
\hat{S}(t)=\prod_{i=1}^{j}\left(1-\frac{d_{j}}{r_{j}}\right)
$$

In survival analysis, the survival function $S(t)$, Probability density function $f(t)$, and risk rate function $h(t)$, their relationship were as follows:

$$
\begin{aligned}
& f(t)=-S^{\prime}(t), \\
& h(t)=-S^{\prime}(t) / S(t)=-d \log s(x) / d x \\
& \left.\log S(x)\right|_{0} ^{t}=-\int_{0}^{t} h(x) d x \\
& S(t)=\exp \left(-\int_{0}^{t} h(x) d x\right)=\exp [-H(t)] \\
& H(t)=\int_{0}^{t} h(t) d u=-\log S(t)
\end{aligned}
$$

$H(t)$, it's called the Cumulative Hazard Function.

\section{Results}

The study use the Kaplan-Meier analysis and Cox model to identify the probability of each entry mode choice and location choice vary across the speed of entry. The results are presented in Figure 1, Figure 2, Figure 3, Figure 4 and Table 1. All our hypotheses are supported. We also conduct many robust checks to ensure our results keep consistent.

\subsection{Kaplan-Meier analysis}

Figure 1 shows the survival curve of the four entry modes of the sample enterprise. The survival time of the horizontal axis is the age of the enterprise and the survival rate of the longitudinal axis is the survival rate. The following information can be obtained from the Figure 1: firstly, with the increase of enterprise age, the survival curve gradually decreases step by step from 1 to 0 . Secondly, the curve of branch entry mode drops steepest, followed by acquisition, WOS and Joint venture.Thirdly, The selected probability of branch entry mode is the highest, followed by acquisition, WOS and joint venture. Log-Rank test statistics and Wilcoxon test statistics show that there is statistical significance at the level of $1 \%$. The result supports hypothesis 1 .

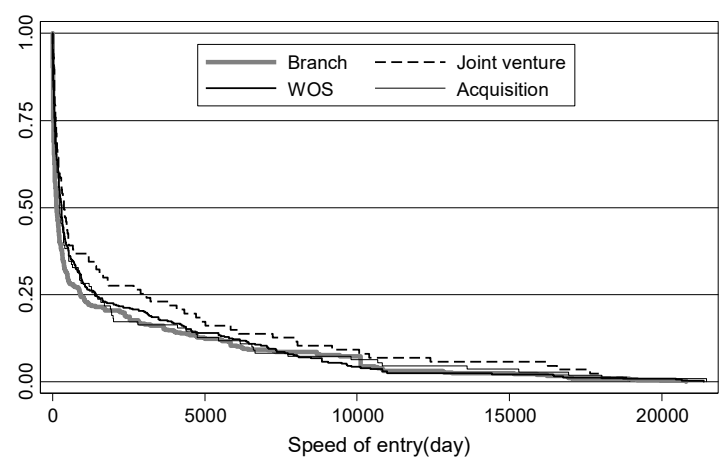

Log-Rank Test $\chi^{2}(3)=10.22^{* *}$;Wilcoxon Test $\chi^{2}(3)=24.65^{* * *}$

Figure 1. Kaplan-Meier survival function, by entry mode

Figure 2 shows the survival curve of market location of the sample enterprise. The survival time of the horizontal axis is the age of the enterprise and the longitudinal axis is the survival rate. The following information could be obtained from the Figure 2: firstly, as enterprises grow older, the survival curve gradually decreases step by step from 1 to 0 . Secondly, the curve of investing to developing countries falls steeper, followed by investing to developed countries. Thirdly, the survival curve indicating that the probability of investing to developing countries is higher than that investing to developed countries. Log-Rank test statistics and Wilcoxon test statistics show that there is statistical significance at the level of $1 \%$. The result supports hypothesis 2 .

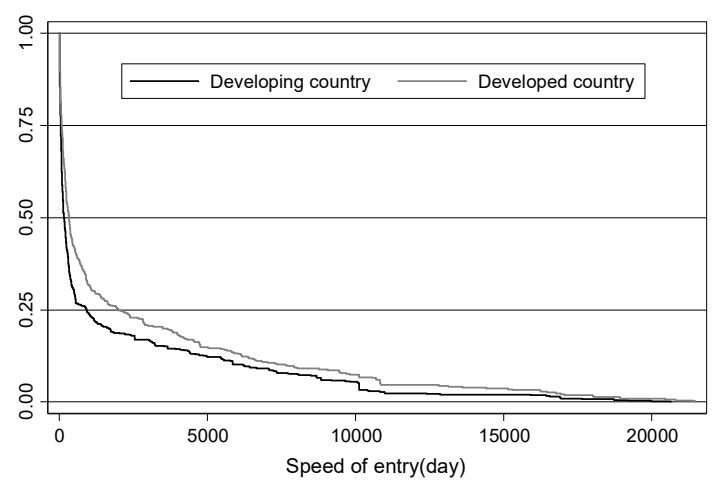

Log-Rank Test $\chi^{2}(1)=6.25^{* *} ;$ Wilcoxon Test $\chi^{2}(1)=12.20 * * *$

Figure 2. Kaplan-Meier survival fuction, by location choice 


\subsection{Cox regression analysis}

The Cox regression results of the internationalization experience of innovative enterprises in China to the entry speed are shown in Table 1. The results of model 2 and model 6 show that: the entry mode experience has an Ushaped relationship with the entry mode of branch $(\mathrm{R}=-$ $0.016, \mathrm{P}<0.05)$ and WOS $(\mathrm{R}=-0.008, \mathrm{P}<0.001)$. The result of model 8 shows that the host country experience has an inverted U-shaped relationship with the entry speed of acquisition $(\mathrm{R}=0.068, \mathrm{P}<0.01)$ (Figure 3$)$. The result of model 10 shows that the entry mode experience has an U-shaped relationship with the entry speed of investment to developing country $(\mathrm{R}=-0.007, \mathrm{p}<$ 0.1 ). The result of model 12 shows that the host country experience has an inverted U-shaped relationship with the entry speed of investment to developed country $(\mathrm{R}=0.019$, $\mathrm{P}<0.01$ ) (Figure 4). Overall, the results in Table 1 support the hypothesis 3 .

Table 1. Empirical results -coefficient of cox model.

\begin{tabular}{|c|c|c|c|c|c|c|c|c|c|c|c|c|}
\hline \multirow{2}{*}{ Variables } & \multicolumn{2}{|c|}{ Branch } & \multicolumn{2}{|c|}{ JV } & \multicolumn{2}{|c|}{ WOS } & \multicolumn{2}{|c|}{ Acquisition } & \multicolumn{2}{|c|}{$\begin{array}{c}\text { Developing } \\
\text { country }\end{array}$} & \multicolumn{2}{|c|}{ Developed country } \\
\hline & Model1 & Model2 & Model3 & Model4 & Model5 & $\begin{array}{c}6 \\
\end{array}$ & Model7 & Model8 & Model9 & Model10 & $\begin{array}{c}\text { Modell } \\
1 \\
\end{array}$ & Model12 \\
\hline $\begin{array}{l}\text { Host country } \\
\text { experience }\end{array}$ & $\begin{array}{c}-0.133 * * * \\
(0.050)\end{array}$ & $\begin{array}{l}-0.107 \\
(0.129)\end{array}$ & $\begin{array}{c}0.078 \\
(0.057)\end{array}$ & $\begin{array}{c}0.088 \\
(0.145)\end{array}$ & $\begin{array}{l}0.051^{*} \\
(0.027)\end{array}$ & $\begin{array}{l}0.019 \\
(0.071)\end{array}$ & $\begin{array}{l}-0.134^{*} \\
(0.070)\end{array}$ & $\begin{array}{c}- \\
0.632 * * * \\
(0.191)\end{array}$ & $\begin{array}{l}-0.012 \\
(0.030)\end{array}$ & $\begin{array}{c}0.005 \\
(0.081)\end{array}$ & $\begin{array}{l}-0.013 \\
(0.028)\end{array}$ & $\begin{array}{c}-0.184 * * * \\
(0.067)\end{array}$ \\
\hline $\begin{array}{l}\text { Entry mode } \\
\text { experience }\end{array}$ & $\begin{array}{c}0.171 * * * \\
(0.044)\end{array}$ & $\begin{array}{c}0.324 * * * \\
(0.079)\end{array}$ & $\begin{array}{l}-0.089 \\
(0.059)\end{array}$ & $\begin{array}{c}-0.293 * * \\
(0.115)\end{array}$ & $\begin{array}{c}0.052 \\
(0.036)\end{array}$ & $\begin{array}{l}0.132 * \\
* \\
(0.061)\end{array}$ & $\begin{array}{c}-0.461 * * * \\
(0.066)\end{array}$ & $\begin{array}{l}-0.280 * \\
(0.148)\end{array}$ & $\begin{array}{c}0.035 \\
(0.029)\end{array}$ & $\begin{array}{l}0.101 * * \\
(0.050)\end{array}$ & $\begin{array}{l}-0.006 \\
(0.027)\end{array}$ & $\begin{array}{l}-0.025 \\
(0.054)\end{array}$ \\
\hline $\begin{array}{l}\text { Host country } \\
\text { experience } \\
\text { squared }\end{array}$ & & $\begin{array}{l}-0.006 \\
(0.020)\end{array}$ & & $\begin{array}{l}-0.003 \\
(0.015)\end{array}$ & & $\begin{array}{c}0.004 \\
(0.007)\end{array}$ & & $\begin{array}{c}0.068 * * * \\
(0.023)\end{array}$ & & $\begin{array}{l}-0.003 \\
(0.010)\end{array}$ & & $\begin{array}{c}0.019 * * * \\
(0.006)\end{array}$ \\
\hline $\begin{array}{l}\text { Entry mode } \\
\text { experience } \\
\text { squared }\end{array}$ & & $\begin{array}{c}-0.016 * * \\
(0.007)\end{array}$ & & $\begin{array}{c}0.016 \\
(0.011)\end{array}$ & & $\begin{array}{l}-0.008^{*} \\
(0.004)\end{array}$ & & $\begin{array}{l}-0.032 \\
(0.022)\end{array}$ & & $\begin{array}{c}-0.007^{*} \\
(0.004)\end{array}$ & & $\begin{array}{c}0.001 \\
(0.005)\end{array}$ \\
\hline Chi2 & 140.68 & 149.69 & 68.74 & 78.06 & 79.51 & 82.94 & 153.91 & 162.36 & 309.92 & 316.66 & 246.62 & 250.89 \\
\hline
\end{tabular}

Standard errors in parentheses; $* * * \mathrm{p}<0.01, * * \mathrm{p}<0.05, * \mathrm{p}<0.1$; Control variables were not shown in Table 1.

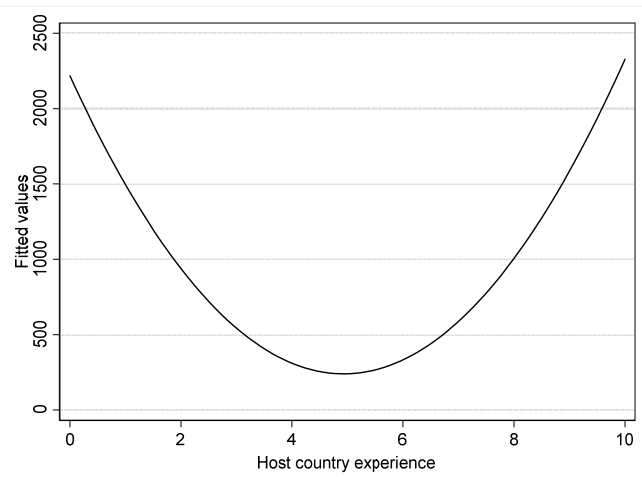

Figure 3. Curvilinear relationship between host country experience and the speed of entry(with the entry mode of acqusition)

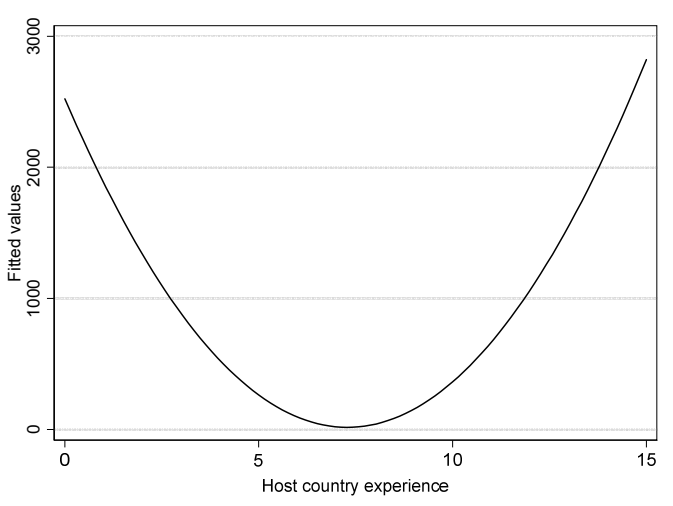

Figure 4. Curvilinear relationship between host country experience and the speed of entry(entry into developed country)

\section{Conclusion}

In summary, we focus on the choice of internationalization of Chinese innovative firms. Based on the perspective of organizational learning, we argue that international experience including the host location experience and entry mode experience has a curve relationship with the speed of entry. Our theoretical arguments and empirical evidence can not only contribute to the emerging literature on IB, but also contribute to a deeper view on the internationalization of emerging economy multinational corporations.

\section{Acknowledgement}

This research was supported by the China Postdoctoral Science Foundation(grant number 2020M673191), Youth Project of National Natural Science Foundation of China (grant number 71802033), National Science Foundation of China (grant number 71974136).

\section{References}

1. S. Athreye, A. Saeed, M.S. Baloch. (2021) Financial Crisis of 2008 and Outward Foreign Investments from China and India. Journal of World Business, 3: 171-190.

2. J. Paul, M.M. Feliciano-Cestero. (2021) Five Decades of Research on Foreign Direct Investment 
by Mnes: An Overview and Research Agenda. Journal of business research, 124: 800-812.

3. A. Wu, L. Zhou. (2018) Understanding Earliness of Internationalization and Its Impact on Postentry Geographic Diversity of International Young Ventures. Journal of International Marketing, 2: 6279.

4. M. Kotabe, T. Kothari. (2016) Emerging Market Multinational Companies' Evolutionary Paths to Building a Competitive Advantage from Emerging Markets to Developed Countries. Journal of World Business, 5: 729-743.

5. H. Jansson, S. Söderman. (2021) Initial Internationalization of Chinese Privately Owned Enterprises - the Take - Off Process. Thunderbird International Business Review, 2: 183-194.

6. P.J. Buckley, X. Liu. (2009) The Determinants of Chinese Outward Foreign Direct Investment. Journal of International Business Studies, 2: 353-354.

7. E. Xie, K.S. Reddy, J. Liang. (2017) Country Specific Determinants of Cross Border Mergers and Acquisitions: A Comprehensive Review and Future Research Directions. Journal of World Business, $2: 127-183$.

8. B. Ramasamy, M. Yeung, S. Laforet. (2012) China's Outward Foreign Direct Investment: Location Choice and Firm Ownership. Journal of World Business, 1: 17-25.

9. Y. Chu, J. Chu, H. Liu. (2020) The Impact of Mergers and Acquisitions on Brand Equity: A Structural Analysis. International Journal of Research in Marketing, doi.org /10.1016/j.ijresmar. 2020.11.006.

10. J. Anderson, D. Sutherland. (2015) Entry Mode and Emerging Market Mnes: An Analysis of Chinese Greenfield and Acquisition Fdi in the United States. Research in International Business \& Finance, C: 88103.

11. J. Paul, G.R. Benito. (2018) A Review of Research on Outward Foreign Direct Investment from Emerging Countries, Including China: What Do We Know, How Do We Know and Where Should We Be Heading? Asia Pacific Business Review, 1:90-115.

12. J.C. Casillas, A.M. Moreno-Menéndez. (2014) Speed of the Internationalization Process: The Role of Diversity and Depth in Experiential Learning. Journal of international business studies, 1:85-101.

13. L. Cui, F. Jiang. (2009) FDI Entry Mode Choice of Chinese Firms: A Strategic Behavior Perspective. Journal of World Business, 4: 434-444.

14. P. Deng. (2009) Why Do Chinese Firms Tend to Acquire Strategic Assets in International Expansion? Journal of World Business, 1:74-84.

15. Y. Luo, R.L. Tung. (2007) International Expansion of Emerging Market Enterprises: A Springboard Perspective. Journal of international business studies, 4: 481-498.
16. J.A. Mathews. (2006) Dragon Multinationals: New Players in 21st Century Globalization. Asia Pacific Journal of Management, 1: 5-27.

17. J. Anderson, D. Sutherland, S. Severe. (2015) An Event Study of Home and Host Country Patent Generation in Chinese Mnes Undertaking Strategic Asset Acquisitions in Developed Markets. International Business Review, 5: 758-771.

18. C.-s. Liou. (2009) Bureaucratic Politics and Overseas Investment by Chinese State-Owned Oil Companies: Illusory Champions. Asian Survey, 4: 670-690.

19. P. Gammeltoft, H. Barnard, A. Madhok. (2010) Emerging Multinationals, Emerging Theory: Macroand Micro-Level Perspectives. Journal of International Management, 2: 95-101.

20. P. Piperopoulos, J. Wu, C. Wang. (2018) Outward Fdi, Location Choices and Innovation Performance of Emerging Market Enterprises. Research Policy, 1: 232-240.

21. A. Cuervo-Cazurra, M. Genc. (2008) Transforming Disadvantages into Advantages: Developing Country Mnes in the Least Developed Countries. Journal of international business studies, 6:957-979.

22. A. Cuervo-Cazurra. (2007) Sequence of ValueAdded Activities in the Multinationalization of Developing Country Firms. Journal of International Management, 3: 258-277.

23. R. Ramamurti. (2007) What Is Really Different About Emerging Market Multinationals? Global Strategy Journal, 1:41-47.

24. J. Johanson, J.-E. Vahlne. (2009) The Uppsala Internationalization Process Model Revisited: From Liability of Foreignness to Liability of Outsidership. Journal of international business studies, 9:14111431.

25. A. Madhok, M. Keyhani. (2009) Acquisitions as Entrepreneurship: Asymmetries, Opportunities, and the Internationalization of Multinationals from Emerging Economies. Global Strategy Journal, 1: 2640.

26. Q. Xie. (2007) Firm Age, Marketization, and Entry Mode Choices of Emerging Economy Firms: Evidence from Listed Firms in China. Journal of World Business, 3: 372-385.

27. P. Padmanabhan, K.R. Cho. (1999) Decision Specific Experience in Foreign Ownership and Establishment Strategies: Evidence from Japanese Firms. Journal of international business studies, 1: 25-41.

28. D.R. Cox, D. Oakes. (1984) Analysis of Survival Data. Chapman and Hall, New York.

29. D.W. Hosmer, S. Lemeshow, S. May. (2011) Applied Survival Analysis: Regression Modeling of Time-toEvent Data, Second Edition, 450:16-66.

30. J.D. Kalbfleisch, R.L. Prentice. (2011) The Statistical Analysis of Time Failure Data. John Wiley \& Sons, New Jersey. 